\title{
School of Pioneer Good Culture
}

\author{
Asri Widiatsih (Corresponding author) \\ IKIP PGRI Jember, Indonesia
}

Rudy Sumiharsono

IKIP PGRI Jember, Indonesia

Dedy Ariyanto

IKIP PGRI Jember, Indonesia

Received: August 8, 2018 Accepted: January 7, 2019 Published: February 25, 2019

doi:10.5296/ijld.v9i1.13483

URL: https://doi.org/10.5296/ijld.v9i1.13483

\begin{abstract}
The Law of the Republic of Indonesia Number 20 of 2003 Chapter XIV Article 50 Paragraph 5 affirms that the Regency/Municipal government administers primary and secondary education, as well as educational units based on local excellence. The purpose of this study is to describe how schools can be good cultural pioneers by understanding the value of local wisdom found in the communities around the school.

The research was conducted in SMP Negeri 2 Kalisat Subdistrict, Jember District. Data collection was done by in-depth interview, observation, and documentation. Data analysis was done by analyzing individual case data. Data validity checking is done through credibility test, transferability test, and confirmability test. The results of the study show that schools can be a cultural pioneer in the community by integrating local wisdom with education. Local wisdom is interpreted as a way of responding to something based on local culture. good culture is a local culture that can be used to improve education Strived this research is able to provide school input how to be a pioneer of good culture. The conclusions of this research are (1) the principals apply alternative leadership, (2) the relationship between school and community structure is non-formal, (3) implementing school relations program with local wisdom-based society.
\end{abstract}

Keywords: Management of school relationship with community, principal leadership, local wisdom 


\section{Introduction}

The rules related to the decentralization have been issued since the reformation of education in Indonesia, namely: (1) The Constitution Number 22 Year 1999 about local government demanding the implementation of regional autonomy and democratic insight in education, (2) Government Regulation Number 25 Year 2000 about the authority of the government and province as autonomous regions in education, (3) The Constitution of the Republic of Indonesia, Number 20 Year 2003 Chapter XIV Article 50 Section 5 emphasizes that the district/city government has a right to manage primary and secondary education, as well as education units based on local excellence, (4) Government Regulation of the Republic of Indonesia Number 19 Year 2005 Chapter III Article 14 Section 1 defines that the curriculum in junior high school (SMP / MTS / SMPLB) or other equivalent degrees, may incorporate local excellence-based education.

Local excellence - based education is education that utilizes local wisdom in the aspects of economy, culture, language, information and communication technology, ecology, and so on, all of which are beneficial to the development of student competence. The potential of each region varies greatly and needs to be improved (Khoiru, 2012). Disclosure of local wisdom associated with the culture, has an important meaning to maintain the continuity and sustainability of culture. Moreover, in the midst of modernization, also known as globalization, the value of local culture can be evicted by foreign cultures that begin to grow rapidly in the community of Indonesia, not only in the urban areas but also in the countryside.

The incredible growth of globalization has emphasized the importance of learning about effective leadership. The leaders are forced to deal with the need of influencing people from different cultures and successful influences require a good understanding of various cultures. Leaders must be also able to understand how people from different cultures view them and translate their actions (Yukl, 2005). Similarly, (Brauckman, dan Pashiardis, 2012) stated that, "The greatnest needs for leadership improvement and training are following three areas: (1) trust building and collaboration: relations with parent and community, promotian of cooperation with other organization and businesses from the community so that students' needs are addresses and initiation of trust building activities within the local community, (2) encouraging instructional leadership and human resources development, (3) initiating school improvement and development". According to its function, education is one of the public service institutions in the service sector. Therefore, education needs to exploit local resources as a reference to improve the quality and service of education.

Lead competence is the key to the success of a change. Not only in the upper layers of the hierarchy, but also in a simpler sense, leadership is in all parts of the organization. By the ability to lead change, any existing obstacles can be overcome easily (Sutrisno, 2010:270). Another important competence is the sensitivity to cultural differences (Sutrisno, 2010:271). This competence is not only related to empathy and diplomacy, but also improvement and understanding of the values, beliefs, and attitudes of people coming from different cultures. The cultural sensitivity is necessary to manage labor changes that is increasingly diverse, and to deal effectively with international management issues, as foreign competition becomes very 
important nowadays, many companies become multinational and conduct joint ventures between countries (Kresna \& Putra, 2002).

Jember is one of the horseshoe areas in East Java, most of which are Madurese. Kalisat sub-district is the northern area of Jember, where the majority of people are ethnically Madurese. Based on preliminaries studies, researchers got information from the District Education Office of Jember in 2012 that the quality of education in Kalisat sub-district is the highest among other sub-districts (Ledokombo, Sukowono and Sumberjambe) in North Jember which the majority of people are Madurese. In this case, we can say that Madurese has an important role in the education quality in di Kalisat sub-district. SMPN 2 Kalisat becomes one of favourite schools in the surrounding community because the local wisdom of Kalisat community is well-understood in this school. The results of the study show that schools can be a cultural pioneer in the community by integrating local wisdom with education. Local wisdom is interpreted as a way of responding to something based on local culture. good culture is a local culture that can be used to improve education. According to the above explanation, researchers were interested in conducting research "School of Good Cultural Pioneer" (Case Study at SMPN 2 Kalisat).

\section{Research Methods}

\subsection{Approach and Type of Research}

The research was conducted using qualitative approach and ethnography design. This study aims to understand how alternative leadership of the headmaster to the cultural change of society. This study aims to understand how schools understand the value of the local wisdom of the surrounding communities so that they can become good cultural pioneers. Ethnography was chosen because it is a type of qualitative research whose focus is describing, analyzing and interpreting group culture. Related to education, as explained by Wiersma \& Jurs (2009) ethnography is, "The process of providing holistic and scientific descriptions of educational systems, processes, and phenomena within their specific contexts". Ethnographic education is the most appropriate method to explore how schools can be a good cultural pioneer.

\subsection{Location of Research}

Kalisat Sub-district of Jember Regency was selected as the research location because of the following reasons: (1) This sub-district is located in North Jember area which means the majority of the population are Madurese, (2) Kalisat sub-district has the highest level of community participation in education compared with other sub-districts in North Jember. Precisely, we carried out the research at SMPN 2 Kalisat.

\subsection{The Presence of Researchers}

According to Bogdan dan Biklen (2003), researchers in qualitative research act as planners, data collectors, analysers, interpreters, and reporters on the results of research. The presence of researchers in the field as full observers and a benchmark for obtaining data validity is expected to support success in understanding the focus of the research. The presence of researchers can directly build a relationship of familiarity with research subjects, a more reasonable 
relationship, and growing trust that researchers do not use the results of research for the interests of the wrong and harm others (Muhadjir, 2000). As a key instrument, researchers relate directly to the subject of research through going directly to the field. Thus researchers will be able to understand what is the subject of research.

\subsection{Data Source}

Ethnographic research can be carried out using participant observation and non-participant observation. More specifically, ethnographic studies are characterized by several types of observations participating at a very clear level. Ethnography also describes multi-instrument research, so ethnographers use various data collection strategies related to observation (Mantja, 1997). Every ethnographer seeks to express what people say to describe their culture. Cultural conclusions carried out by ethnographers through three sources, namely (1) from what people say, (2) from what people do, and (3) from artifacts used by people thus stated by Spradley (1980).

\subsection{Data Collection Technique}

Qualitative research is naturalitic research by obtaining descriptive data, so ethnographic researchers also utilize data collection techniques used in qualitative research in general, but there are some typical techniques. The techniques for collecting data in ethnographic research are as follows: (1) in-depth interviews, (2) life history, (3) participant observation, (4) focus group discussions (FGD), and (5) document analysis.

In-depth interviews are a series of questions posed by researchers to the subject of research. Because of the naturalistic ethnographic character, then the form of the question or interview conducted is an open question and its nature flows, however to maintain the focus of the research it is a good idea for a researcher to have an interview guide that is flexible. Every interview conducted, the researcher must deepen it by making notes on the results of interviews and observations. Interview activities will always produce new questions whose nature deepens what has been received from the subject of research. In the context of deepening the data, the interview process can be done spontaneously or planned. The information obtained is then developed to gather information from other informants so that information about community participation is more complete (snow ball).

Data in the interview process and supported by other documents and records can be life history which is a long and detailed record of the life history of the research subject. This is in line with Tacci, J. (2003), "You can get very rich material by asking for their ownlives through diares, photography projects, sound recording and other media." Through this historical record of ethnographic researchers will understand in detail what is the life of the research subject and the factors that influence it include the culture that exists in the environment. Historical records of life, require the ability of researchers to be observant in seeing every detail of a person's life, so clearly illustrated how "the way" of the life of research subjects from birth to adulthood so that important events that become turning points in the life history of research subjects. Although almost the same as the autobiographical pattern, but there are differences, especially in a stronger effort in writing to avoid the subjectivity of the author. 
Participant observation is used to find out in direct detail how the culture of an individual or a group of people, then an ethnographic researcher must be an "insider". Being an "insider" will benefit researchers in producing data that is natural. Researchers will know and understand what the subject of research, daily behavior, habits that are carried out daily, to the understanding of the life symbols of research subjects in everyday life that can be other people do not understand what the symbol really is. Researchers who become insiders can "uncover" all things without the slightest obstacle, because the research subject will feel that the presence of the researcher is like a part of his family, so there is no doubt and obstacle for the subject to behave naturally, just as he lives in daily life. Being an insider through participant observation does not make the researcher dissolve until he cannot distinguish himself from the subject of the research. This position must be truly guarded in conducting ethnographic research.

The stages of observation according to Spradley (1980) there are three, namely: (1) descriptive observations conducted by researchers when entering certain social situations as objects of research, (2) focused observations namely an observation that has been narrowed to focus on certain aspects, (3) selected observations by outlining the focus found so that the data is more detailed.

Focus group discussion is a joint discussion activity between researchers and research subjects in a directed manner. Focus group discussions (FGDs) are used, with consideration because the intensity of the problem and the new prospect will be found accurately if the informant is involved cognitively and emotionally in a forum or opportunity for focused discussion. Tacci. J. (2003) argues that, "Group interview, sometimes called" focus group "is simply in depth with more than one person interviews. The aim is generally similar to individual in depth interviews - to gain rich and often exploratory material. However, there is also another content statement to consider here: group dynamics"

The ability of the researcher to present the main issue or theme, package it and then discuss and manage the discussion becomes directed in the sense that the discussion process remains within the theme area and is not too broad especially to include subject emotions excessively as the keywords of a good FGD process. Focus group discussions can begin with the selection of discussion members previously determined by the researcher, or can be done randomly, but still pay attention to the "strength" of each discussion participant, starting from the level of education, intellectuality, experience and even gender balance. This determination is a step to avoid inequality or the dominance of one group or individual in a discussion. Then, continued with the theme that will be carried out by the researcher, and discussed together. This process is then recorded by the researcher in detail to be used as a basis for deepening and enriching ethnographic data.

Document analysis is needed to answer questions to be directed, in addition to increasing research understanding and information. Since not all of the research sites have documents available, it is a good idea for a researcher to ask questions about informants who can help decide what types of documents might be available. Document requirements depend on the researcher, but researchers must be aware of the limitations of the document, and researchers may try to understand the available documents, which might help understanding. 


\section{Macrothink}

International Journal of Learning and Development

ISSN 2164-4063 2019, Vol. 9, No. 1

Various techniques for collecting data that are exposed can be used by researchers simultaneously or selected by researchers based on their needs and also depend on the researcher in maximizing the instrument. The researcher must try to obtain and produce detailed and intact ethnographic data.

\section{Result and Discussion}

The school can understand the value of the local wisdom of the surrounding community so that it can become a cultural pioneer for the community by doing the following:

\subsection{Headmaster Leads Change}

A leader who wants a change will act as a change agent. A change agent is expected to always be alert to situations or people in need, open to any brilliant ideas, and able to support the implementation of these new ideas in real practice (Schermerhon, 1996). An agent of change is not only the type of leader who is merely ready to respond to change, but also ready to make the change by himself when it is necessary.

A leader of change must be able to understand how changes in the external environment will have an impact on the organization. The change requires a strategic planning of the leaders, which needs sufficient ability to analyze perceived events and trends, anticipate changes, and recognize potential opportunities and problems (Sutrisno, 2010: 258)

The existing problems and challenges are managed with alternative leadership utilizing Intellectual Intelligence (IQ), Emotional Intelligence (EQ) and Spiritual Intelligence (SQ) which are closely related to each other. The mechanism of the relationship between those three intelligences is called Meta Intelligence (Ginanjar, 2007) that can be illustrated in Figure 1 below. 

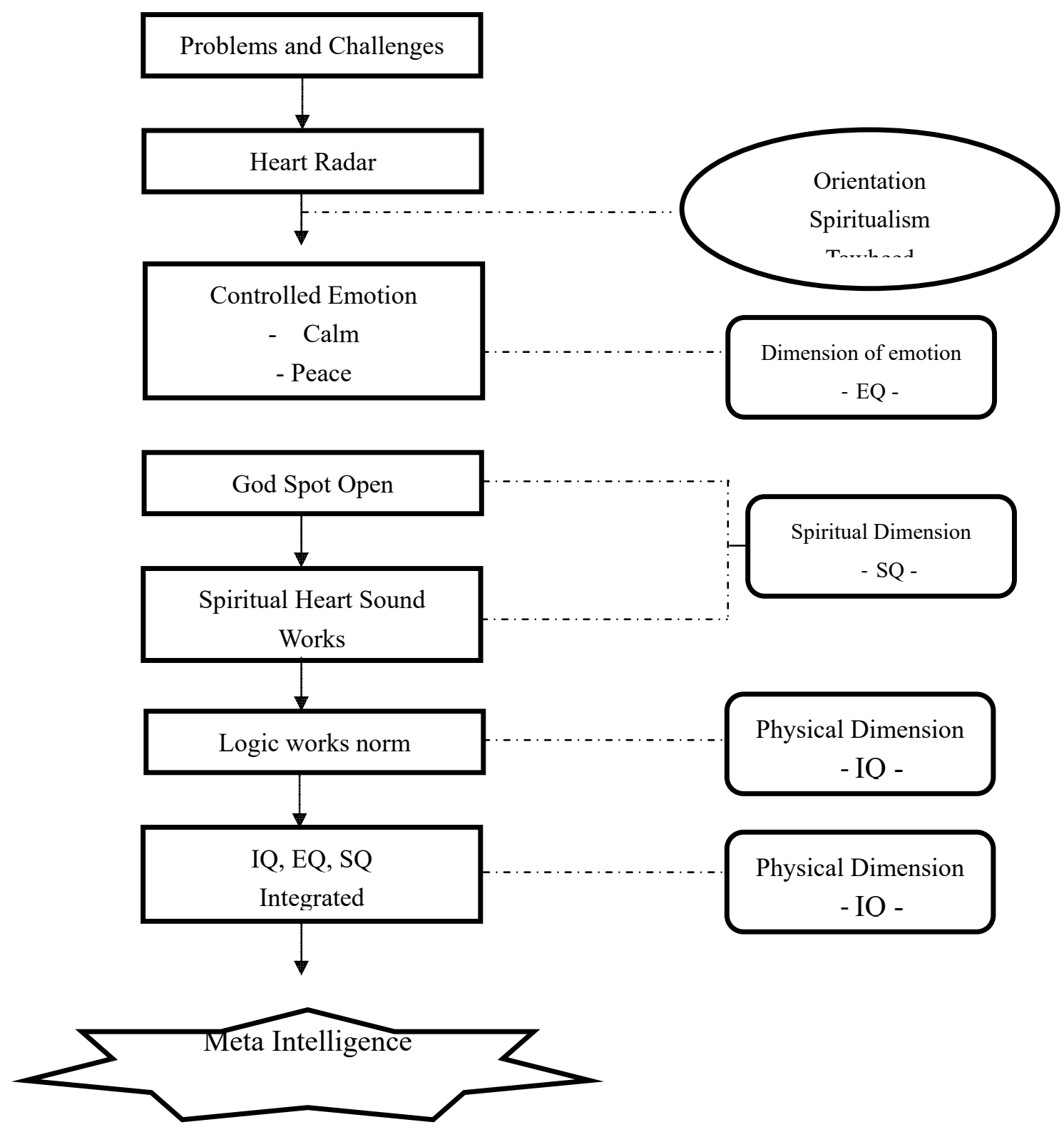

Picture 1. Meta Intelligence (adapted from Ginanjar, 2007:219)

When problems and challenges arise (1) the heart radar instantly captures the vibrations of the signal, (2) when the signal touches the wall of Tawheed, the consciousness of Tawheed controls the emotions. The result is a controlled emotion, such as a sense of calm and peace. With the emotional calm that is controlled then God Spot or the door of the heart opens and works. The whispering of ilahihiah emerges to invite us to the qualities of: justice, compassion, honesty, responsibility, caring, creativity, commitment, togetherness, peace and other noble deeds. According to that noble whisper encouragement, the potential of intellectual intelligence works optimally, that is an intellectual calculation based on the values of justice, honesty and responsibility. Thus, a Meta Intelligence is born which is an integration of IQ, EQ and SQ. 
In SMPN 2 Kalisat, decision making that utilizes IQ, EQ and SQ appears when problems arise. For example, there were ten children threatened not to be able to take the national exam because of their lack of attendance. At that time, there was a conflict at school, "is it necessary to help them or not?" Finally the school decided to help them in the hope that in the future they would be future leaders. Thus, a special team was formed, that was informal, to help them by investigating the reason of their absence. Eventually, it turned out that those children were present because of their family's economic problems.

Based on the advice of special team, the headmaster decides to help them by giving alms daily as pocket money, and buying shoes and bags for them. The donations also came from the teachers and officers. They work together by setting aside some of their income every day. They did it willingly due to their belief that when helping others they will get a reward from God. This shows that spiritual intelligence (SQ) is the basis of their actions. The purchase of bags and shoes was done because they only had one bag and one pair of shoes. In the case of rain, they would have other bag and shoes to wear so that they would not skip school. Those children were eventually able to take the national exam. The headmaster and all staff felt a great blessing after helping them. Their religious beliefs and sense of empathy dredge the headmaster to do something for those children to take the national exam. Thus, spiritual intelligence (SQ) and emotional intelligence (EQ) become the basis for intellectual intelligence (IQ).

\subsection{Organizational Structure of Relationship Between School and Non-Formal Community}

The organizational structure in management of relationship between school and the community in SMPN 2 Kalisat is non-formal. This corresponds to the opinion of Robbins (1994) that the type of changes created by management is various, one of which is structural change. Structural changes focus on techniques that have an impact on the organizational structure system.

In accordance with Sutrisno's opinion (2010: 88), one of the change mechanisms is through traditional culture change towards quality culture through organizations. Traditional culture through hierarchy is based on the chain of command into a quality culture with the participation and empowerment of employee. A non-formal organizational structure in the management of relationship between school and the community is considered more appropriate to address problems relating to parents or guardians of students as members of the local community.

When dealing with students who are in trouble, SMPN 2 Kalisat assigns a Special Team to find the solutions. This special team is formed not based on structural positions in SMPN 2 Kalisat. They consist of five people who understand the local wisdom of the Kalisat community and have high loyalty to the school. This team usually visits the house of the students to investigate. For example, the case of the students who might not be able to take the national exam because of the lack of their presence in school, the team went to investigate the cause of the problem. In the end, the team figured out that the reason of this problem was mostly due to family's economic issues. Therefore, the school decided to help the students in need such as giving them a pocket money, a bag and one pair of shoes. 
The finding of the special team was used as the basis for taking action in SMPN 2 Kalisat. The action taken by SMPN 2 Kalisat was by collecting funds from educators, education personnel and students. The funds were used to assist students in need to meet their living expenses and allowances. After re-data collection to classes in order to see who only had one bag and a pair of shoes, it turned out to be more than one hundred students. SMPN 2 Kalisat then bought bags and shoes for those students.

\subsection{Integrating Local Wisdom into Program of Relationship Between School and Community}

Integrating local wisdom into program of relationship between school and community includes several programs of: (1) education, (2) humanity, (3) culture, and (4) partnership (Widiatsih, 2017).

\section{1) Educative Relationship}

The form of educative relationship between school and community can be seen from the formation of the school committee. The formation of this school committee consists of a chairman who comes from community leaders, representatives of education. School also holds an educative relationship by holding meeting between school and parents about the problems faced by students.

SMPN 2 Kalisat has a special team to handle the problems faced by students such as those who have been betrothed by their parents, often not attending school. The team will visit their homes to pick up or solve the students' problems. When parents or guardians are invited to school, they always come because they feel shy.

The local content held at SMPN 2 Kalisat is Madurese Language, reading and writing Al Quran. Every morning around 07.00 - 07.07, students have to take turns with officers to read Al Quran in each class and being heard by everyone at school. At the time of the national examination, istigosah (pray together) is always held with notices to parents in advance.

\section{2) Ethics Relationship}

Other ethical relationship conducted by the school is visiting the house of parents when a student is sick, or one of the parents who is passed away. In addition, the students are also involved to contribute to the community or other parents who are unfortunate or passed away. This will teach the students to have a sense of solidarity and concern for others, especially those in the vicinity.

SMPN 2 Kalisat also conducts humanitarian programs in school relations with the community, such as visiting the sick students, helping the needy students and giving the sacrificial meat at the Eid Al-Adha.

\section{3) Cultural relationship}

The cultural relationship between school and community is represented by the selection of teaching materials and methods which are partially adapted to the circumstance of surrounding community. For example in extracurricular activities and local content. Local content used in the ninth grade in Kalisat is the language of Madura. Extracurricular activities also pay 
attention to regional culture as festive highly favored by the people of Kalisat that formed the marching band. On the activities of the great days of Islam, school often involves the community to participate in the event at school. For example, to commemorate the birth of Prophet Muhammad SAW, Isro Miroj, Eid al-Adha, and so on.

SMPN 2 Kalisat has existed since 1986 and has a drum band that is often invited by Kalisat community to perform in the events such as the celebrations of Isro Miroj, seven months pregnant woman, pilgrimage and so on.

The head of the committee of SMPN 2 Kalisat is a teacher who is highly respected by the surrounding community. The programs or policies of school are delivered very well by the head of the committee so that parents or guardians of students are always supportive. For instance the needy student assistance program, there is always consensus deliberation so that all students can get help.

\section{4) Institutional Relationship}

The school also has good relationship with other agencies such as the police or Danramil, subdistricts, and also with other schools. The schools often invite the relevant stakeholders to the school farewell party which is usually held every June or July at the end of the academic year. Sometimes, the school organizes activities with the relevant stakeholders, such as the police to organize carnival band or drum team who will perform to celebrate independence day. The well-relationship with the elementary schools can be seen when the new students are enrolled collectively and coordinated by the headmaster.

SMPN 2 Kalisat also collaborates with related stakeholders such as teachers and elementary school principals, religious leaders and teachers, and the surrounding community. Teachers and elementary school headmasters sometimes send some graduated students to enroll in SMPN 2 Kalisat. Religious leaders and teachers are often invited to SMPN 2 Kalisat when there was an event to celebrate Islamic religious holidays such as the Prophet's birthday. SMPN 2 Kalisat also works with the surrounding community such as to provide parking lot for students who bring motorcycles to school.

\section{Conclution}

Based on the results of research and discussion then to become a good cultural pioneer school: (1) Principals must lead change by utilizing IQ, EQ and SQ in dealing with problems and challenges, (2) Implementing a non-formal organizational structure in the management of school relations with the community so that problems related to parents and society can be resolved quickly and well, and (3) the School integrates local wisdom in school relations programs with the community both in educational programs, humanitarian programs, cultural programs and partnership programs.

\section{References}

Bogdan, R.C. \& Biklen, S. K. (2003). Qualitative Research for Education (An Introduction to Theories and Methods) (4th ed.). Boston: Allyn \& bacon, Inc. 


\section{Macrothink}

International Journal of Learning and Development

ISSN 2164-4063 2019, Vol. 9, No. 1

Braukmann, S., \& Pashiardis, P. (2012). Contextual Framing for School Leardership Training: Empirical Finding from the Project on Leardershing Assesment and Development (Co-LEAD). Journal of Management Development, 31(1), 18-33. https://doi.org/10.1108/02621711211190970

Ginanjar, A. (2007). ESQ Power. Jakartta: Penerbit Arga

Yukl, G. (2005). alih bahasa: Budi Supriyanto, Kepemimpinan Dalam Organisasi. Intan Sejati: Jakarta.

Robbins, S. P., \& Coulter. (1999). Management (6th ed).Upper Saddle River, NJ: Prentice Hall International, Inc.

Khoiru, I. A. (2012). Mengembangkan Pendidikan Berbasis Keunggulan Lokal. Prestasi Pustaka: Jakarta.

Mantja, W. (2008). Etnografi: Desain Penelitian Kualitatif Pendidikan dan Manajemen Pendidikan. Jakarta: Salemba Empat.

Miles, M. B., \& Huberman, A. M. (1992). Analisa Data Kualitatif. Terjemahan Tjetjep Rohendi. Jakarta: UI Press.

Miles, H., \& Saldana. (2014). Qualitative data Analysis. California: Sage Publications.

Schermerhorn, J. R. (1996). Management. New York: John Willer \& Sons.Inc

Spradley, J. (1997). Metode Etnografi. Terjemahan Misbah Zulfa Elizabeth. Yogyakarta: Tiara Wacana Yogya

Spradley, J. (1980). Participant Observation. Holt: Rinehart and Winston.

Sutrisno, E. (2010). Budaya Organisasi. Jakarta: Prenadamedia Group.

Terry, G. R. (1978). Principle of Management. Chicago, IL: Richard D. Irwin Inc.

Undang-Undang N. T. (2003). tentang Sistem Pendidikan Nasional. Bandung: Citra Umbara

Widiatsih. (2017). Manajemen Hubungan Sekolah dengan Masyarakat Berbasis Kearifan Lokal Etnis Madura untuk Meningkatkan Mutu Pendidikan. Disertasi tidak diterbitkan. Malang: Universitas Negeri Malang.

\section{Copyright Disclaimer}

Copyright for this article is retained by the author(s), with first publication rights granted to the journal.

This is an open-access article distributed under the terms and conditions of the Creative Commons Attribution license (http://creativecommons.org/licenses/by/4.0/). 